\title{
PERAN SELF-REGULATED LEARNING TERHADAP EMOTIONAL EXHAUSTION YANG DIMEDIASI OLEH STUDENT ENGAGEMENT PADA SANTRI
}

\author{
Dinda Nabila Sholihah ${ }^{1}$, Riana Sahrani ${ }^{2}$, dan Rahmah Hastuti ${ }^{3}$ \\ 1Program Studi Psikologi Profesi Jenjang Magister, Universitas Tarumanagara Jakarta \\ Email: abby.mpsi@gmail.com \\ ${ }^{2}$ Fakultas Psikologi, Universitas Tarumanagara Jakarta \\ Email: rianas@fpsi.untar.ac.id \\ ${ }^{3}$ Fakultas Psikologi, Universitas Tarumanagara Jakarta \\ Email:rahmahh@fpsi.ac.id
}

Masuk : 16-11-2019, revisi: 25-11-2019, diterima untuk diterbitkan : 26-11-2019

\begin{abstract}
ABSTRAK
Santri merupakan seseorang yang belajar agama Islam dan mendalami agama Islam dalam sebuah pesantrian atau pesantren. Dalam menjalankan kegiatannya sehari-hari, santri terikat dengan berbagai macam peraturan dan kegiatan yang menyebabkan kecenderungan dari munculnya emotional exhaustion pada santri. Dalam penilitian ini, akan dibahas mengenai peranan self-regulated learning terhadap emotional exhaustion yang dimediasi oleh student engagement pada santri. Metode yang digunakan adalah kuantitatif non-eksperimental dengan teknik pengambilan data purposive sampling dan criterion sampling. Adapun alat ukur yang digunakan terdiri dari alat ukur selfregulated learning yang diadaptasi dari alat ukur self-regulated learning dari Pintrich dan Groot (1990), alat ukur emotional exhaustion yang diadaptasi dari alat ukur yang dikembangkan oleh Schaufeli, Martínez, Marqués-Pinto, Salanova, dan Bakker (2002), serta alat ukur student engagement yang diadaptasi dari alat ukur student engagement dari Schaufeli dan Bakker (2003). Pengambilan data dilakukan di lima pondok pesantren yang terdapat di wilayah Bogor dan Bekasi pada bulan Oktober - November 2018 dengan melibatkan 424 partisipan penelitian berusia 11 20 tahun. Berdasarkan hasil yang diperoleh, self-regulated learning secara negatif signifikan memengaruhi emotional exhaustion ( $\mathrm{t} c^{\prime}=-6,336 ; \mathrm{p}=0,000<0,05$ ) dan student engagement tidak memediasi peran self-regulated learning terhadap emotional exhaustion $\left(\mathrm{t} b^{\prime}=1,153 ; \mathrm{p}=0,250>0,05\right)$.
\end{abstract}

Kata kunci: self-regulated learning, emoional exhaustion, student engagement, santri.

\section{ABSTRACT}

A santri is a person who studies Islam in a pesantren or Islamic boarding school. In carrying out their daily activities, students are bound by a variety of regulations and activities that tend to cause emotional exhaustion in students. In this research, the role of self-regulated learning on emotional exhaustion mediated by student engagement on santri will be discussed. The research method used is quantitative non-experimental technique with purposive sampling and criterion sampling. The measuring device used consists of a self-regulated learning measuring instrument adapted from a self-regulated learning measuring instrument from Pintrich and Groot (1990), an emotional exhaustion measuring instrument adapted from a measuring instrument developed by Schaufeli, Martínez, Marqués-Pinto, Salanova, and Bakker (2002), as well as student engagement measurement instrument adapted from the student engagement measurement instrument from Schaufeli and Bakker (2003). Data were collected at five Islamic boarding schools in Bogor and Bekasi over October - November 2018 involving 424 research participants aged 11-20 years. Based on the results obtained, self-regulated learning negatively and significantly affects emotional exhaustion ( $\left.t c{ }^{\prime}=-6.336 ; \mathrm{p}=0.000<0.05\right)$ and student engagement does not mediate the role of self-regulated learning on emotional exhaustion $\left(\mathrm{tb}^{\prime}=1.153 ; \mathrm{p}=0,250>0,05\right)$.

Keywords: self-regulated learning, emotional exhaustion, student engagement, santri. 


\section{PENDAHULUAN}

\section{Latar Belakang}

Emotional exhaustion pertama kali diperkenalkan oleh Freudenberger pada tahun 1974 (dikutip Rigg, Day, \& Adler, 2013) sebagai salah satu dimensi dalam konsep burnout. Burnout terjadi ditandai oleh tiga fase, pertama yaitu munculnya emotional exhaustion, dan personal (Maslach dikutip dalam Rahmati, 2015). Seseorang yang mengalami burnout, biasanya akan memiliki motivasi yang rendah, ketidakpuasan terhadap pekerjaannya, memiliki risiko gangguan kesehatan, dan penurunan terhadap keyakinan mengenai kemampuan dirinya sendiri (Rigg et al., 2013). Seiring berjalannya waktu, konsep burnout semakin diperluas yang semula dianggap hanya dapat terjadi pada karyawan, tetapi saat ini burnout juga dianggap dapat terjadi pada siswa (Balogun et al., dikutip dalam Rigg et al., 2013). Burnout dinilai sangat mungkin terjadi pada siswa. Meskipun, secara tidak formal siswa dianggap tidak bekerja atau tidak memiliki pekerjaan. Namun, jika ditinjau dari pandangan psikologis kegiatan inti siswa dapat dianggap sebagai pekerjaan. Dalam kegiatannya, siswa terlibat dalam kegiatan yang terstruktur dan bersifat mengikat, misalnya seperti menghadiri kelas dan menyelesaikan tugas yang diarahkan untuk mencapai tujuan tertentu, salah satunya lulus ujian (Schaufeli \& Taris dikutip dalam Hu \& Schaufeli, 2009).

Salah satu studi di China, menjelaskan bahwa pendidikan merupakan hal yang dianggap sangat serius. Hal tersebut diketahui berdasarkan kondisi bahwa ujian menjadi sangat kompetitif dalam mengatur penerimaan calon siswa baru di sekolah menengah maupun Universitas hingga dapat menentukan prospek karir siswa. Di China, kualitas guru dinilai berdasarkan hasil ujian siswa. Secara tidak langsung, hal ini berkaitan dengan gaji dan reputasi guru. Akibatnya, para guru memberikan tekanan yang lebih besar pada siswa untuk memperoleh hasil yang maksimal (Hu \& Schaufeli, 2009). Oleh karena itu, meskipun semula hanya dianggap sebagai fenomena yang berhubungan dengan pekerjaan, burnout juga dapat terjadi pada siswa yang dimanifestasikan sebagai perasaan lelah karena tuntutan belajar serta perasaan tidak kompeten sebagai siswa (Hu \& Schaufeli, 2009).

Studi lain mengenai burnout pada siswa juga pernah dilakukan di Korea, Belanda, Spanyol, Portugis, Jerman, dan Turki (Rőmer, 2016). Di Korea, studi tersebut dilakukan karena melihat besarnya tuntutan yang diberikan terhadap siswa SMA tingkat akhir yang akan melakukan seleksi ujian masuk Perguruan Tinggi. Siswa memiliki tingkat kesulitan dan stres yang lebih tinggi dibandingkan dengan mahasiswa. Oleh karena itu, di Korea, studi tersebut lebih difokuskan pada siswa, bukan pada mahasiswa (Römer, 2016). Salah satu dimensi burnout yang paling dianggap penting adalah emotional exhaustion. Berdasarkan tiga dimensi dari burnout, emotional exhaustion merupakan salah satu dimensi yang paling sering dilaporkan terjadi dan paling sering diteliti. Emotional exhaustion dinilai sebagai kualitas sentral dari burnout. Ketika seseorang mendeskripsikan bahwa dirinya telah mengalami burnout, orang tersebut lebih sering menunjukkan pengalamannya dalam mengalami emotional exhaustion (Maslach, Schaufeli, \& Leiter, 2001). Seseorang yang mengalami emotional exhaustion cenderung akan mudah merasa cemas dan frustrasi terhadap aktivitas yang dilakukannya (Maslach et al., 2001). Pada siswa, dampak buruk yang dapat terjadi akibat emotional exhaustion adalah hilangnya semangat dalam melakukan kegiatannya, munculnya gangguan kesehatan, serta munculnya gangguan dalam relasi sosial (Tuithof et al., 2017).

Emotional exhaustion dapat terjadi pada siswa dikarenakan pengalaman stres yang berlebihan akibat dari adanya tuntutan tugas yang terus-menerus, kepribadian, adanya batas waktu dalam menyelesaikan tugas, dan tingginya tuntutan dari lingkungan dapat memperburuk stres pada 
siswa (Schaufeli, Martinez, Marques Pinto, Salanova, \& Bakker dikutip dalam Rigg et al., 2013). Berdasarkan penjelasan tersebut, peneliti tertarik untuk melakukan penelitian mengenai emotional exhaustion terhadap santri. Hal ini dikarenakan tuntutan dalam kehidupannya seharihari. Dalam Kamus Besar Bahasa Indonesia atau KBBI (2018), santri adalah seseorang yang mendalami ilmu agama Islam. Secara umum, santri diartikan sebagai siswa yang belajar dan mendalami agama Islam di sebuah pesantrian atau pesantren yang menjadi tempat belajar bagi para santri (Hidayat, 2016).

Adapun beberapa kegiatan sehari-hari yang biasa dilakukan santri di dalam pesantren antara lain sholat Subuh berjamaah di masjid, tadarus atau membaca Al-Quran berikut dengan menghafal Al-Quran, dilanjutkan dengan kegiatan olahraga, persiapan belajar di dalam kelas dan makan pagi, kegiatan belajar di dalam kelas, sholat Dzuhur berjamaah, makan siang, istirahat, sholat Ashar berjamaah, mengaji kitab kuning berikut dengan hafalan Al-Quran, berolahraga, persiapan sholat Magrib, mengaji Al-Quran, makan malam, sholat Isya berjamaah, belajar kitab kuning, mufrodat atau belajar bahasa Arab, belajar, dan istirahat. Kegiatan tersebut dilakukan berulang pada setiap harinya (Saridjo, 1983). Salah satu cara yang dapat digunakan untuk mengukur tingkat emotional exhaustion pada siswa (dalam hal ini siswa yang dimaksud adalah santri) yaitu dengan menggunakan Maslach Burnout Inventory-Student Survey atau yang umumnya disingkat sebagai MBI-SS (Hu \& Schaufeli, 2009). Dalam MBI-SS tercakup tiga buah dimensi, antara lain emotional exhaustion, cynicism, dan academic efficacy. Mengacu pada dimensi dalam MBI-SS, konsep lain menyebutkan bahwa terdapat teori yang menjelaskan mengenai kebalikan dari konsep burnout, yaitu work engagement (Rőmer, 2016). Hal ini didasari oleh dua dimensi bipolar yang tercakup di dalamnya, seperti aktivasi yang merupakan kelanjutan dari emotional exhaustion ke vigor, serta identifikasi yang merupakan kelanjutan dari cynicism ke dedication (Rőmer, 2016).

Work engagement muncul sebagai fenomena dari adanya psikologi positif, khususnya pada karyawan dan pelajar (Capri, Gunduz, \& Akbay, 2017). Semula, work engagement hanya diteliti pada karyawan. Namun, saat ini work engagement juga banyak diteliti di kalangan pelajar, baik siswa maupun mahasiswa yang dikenal dengan istilah student engagement (Wickramasinghe, Dissanayake, \& Abeywardena, 2018). Student engagement diartikan sebagai partisipasi aktif siswa di sekolah yang melibatkan energi dan usaha yang keras (Wolters \& Taylor, 2012). Secara histori, student engagement berfokus pada peningkatan prestasi, perilaku positif, dan adanya rasa memiliki dalam diri siswa. Sehingga, siswa tersebut akan tetap bersemangat untuk sekolah (Taylor \& Parsons, 2011). Siswa dengan student engagement yang tinggi akan memiliki rasa ketelibatan dengan fasilitas dan peluang yang disediakan oleh sekolahnya. Sehingga, hal ini akan berdampak pada peningkatan proses pembelajaran, nilai, dan pengembangan diri pada siswa itu sendiri (Carini, Kuh, \& Klein; Kuh, Chen, \& Laird dikutip dalam Abdullah, Teoh, Roslan, \& Uli, 2015). Selain itu, siswa dengan student engagement yang tinggi juga memiliki regulasi diri yang baik pula dalam proses belajarnya (Pizzimenti \& Axelson, 2015). Dalam konteks psikologis, regulasi diri dalam proses belajar dikenal dengan istilah self-regulated learning (Pizzimenti \& Axelson, 2015). Student engagement dan self-regulated learning, keduanya menggambarkan teori dan kerangka penelitian yang digunakan untuk memahami fungsi dan kemampuan siswa dalam konteks akademis (Wolters \& Taylor, 2012).

Self-regulated learning merupakan kemampuan untuk mengatur suatu tugas yang diberikan (Snowman, McCown, \& Biehler, 2009). Self-regulated learning dapat dilihat sebagai sebuah proses aktif yang digunakan oleh siswa untuk menetapkan sebuah tujuan dalam proses belajar siswa tersebut. Kemudian, self-regulated learning juga digunakan siswa untuk memonitor tugas- 
tugas yang mereka miliki, regulasi atau pengaturan diri, serta pengaturan kognisi, motivasi, dan perilaku siswa tersebut dalam mencapai tujuan pembelajaran (Pintrich; Wolters , Pintrich, \& Karabenick dikutip dalam Wolters \& Taylor, 2012). Siswa dengan self-regulated learning yang tinggi akan menunjukkan perilaku proaktif dalam proses belajarnya dengan memanfaatkan pengetahuan dan menekan kemungkinan kesalahan yang muncul sesuai dengan keadaan atau situasi pembelajarannya (Zimmerman dikutip dalam Schunk \&Zimmerman, 2012). Umumnya, siswa dengan self-regulated learning yang tinggi akan memiliki prestasi yang tinggi pula (Anderman \& Anderman dikutip dalam Santrock, 2012).

Berdasarkan penjelasan tersebut, peneliti tertarik untuk melihat peran self-regulated learning terhadap emotional exhaustion yang dimediasi oleh student engagement. Hal ini didasari oleh adanya penelitian yang menjelaskan hubungan emotional exhaustion dengan student engagement (Rőmer, 2016) dan hubungan antara self-regulated leaning (Pizzimenti \& Axelson, 2015). Baron dan Kenny (1986) menjelaskan salah satu kriteria dari variabel mediator adalah variabel mediator tersebut dipengaruhi oleh independent variable penelitian (bertindak sebagai dependent variable) dan variabel mediator tersebut juga memberikan dampak terhadap dependent variable penelitian (menjadi independent variable).

\section{Rumusan Masalah}

Adapun rumusan masalah dalam penelitian ini antara lain:

1. Apakah self-regulated learning berpengaruh terhadap student engagement?

2. Apakah self-regulated learning berpengaruh terhadap emotional exhaustion?

3. Apakah student engagement berpengaruh terhadap emotional exhaustion?

4. Apakah terdapat peran self-regulated learning terhadap emotional exhaustion yang dimediasi oleh student engagement pada santri?

\section{METODE PENELITIAN}

Penelitian ini melibatkan 424 partisipan penelitian dengan jumlah partisipan laki-laki sebanyak 221 orang $(52,1 \%)$ dan perempuan sebanyak 203 orang (47,9\%). Partisipan penelitian merupakan santri yang tinggal di dalam pondok pesantren selama enempuh pendidikannya. Partisipan penelitian berada pada rentang usia 11-20 tahun. Desain yang digunakan dalam penelitian ini adalah penelitian kuantitafif non-eksperimental. Pengambilan data dilakukan dengan menggunakan kuesioner. Adapun teknik pengambilan sampel yang digunakan peneliti adalah dengan menggunakan teknik criterion sampling dan teknik purposive sampling. Pada teknik criterion sampling, pengambilan data dilakukan dengan cara melakukan screening terhadap kriteria dari calon partisipan penelitian. Dalam teknik ini, partisipan penelitian dipilih berdasarkan kriteria yang telah ditetapkan. Teknik berikutnya yaitu purposive sampling. Pada teknik ini, partisipan penelitian diperoleh berdasarkan adanya rujukan dari suatu pihak. Sehingga, partisipan penelitian yang diperoleh dapat menjawab pertanyaan penelitian sesuai dengan tujuan penelitian. Dalam penggunaannya, banyaknya jumlah partisipan penelitian yang diperoleh menggunakan teknik ini tidak ditentukan secara pasti.

\section{Pengukuran}

Dalam penelitian ini digunakan tiga buah alat ukur, yaitu Motivated Strategies for Learning Questionnaire atau MSLQ yang merupakan adaptasi dari Pintrich \& Groot (1990) untuk mengukur self-regulated learning; Maslach Burnout Inventory - Student Survey atau MBI-SS yang merupakan adaptasi dari Schaufeli, Martínez, Marqués-Pinto, Salanova, dan Bakker (2002) untuk mengukur emotional exhaustion; dan Utrecht Work Engagement Scale-Student atau 
UWES-S yang diadaptasi dari Schaufeli dan Bakker (2003) untuk mengukur student engagement.

MSLQ dibuat dengan menggunakan tujuh skala $(1=$ sangat-sangat tidak sesuai sampai $7=$ sangat-sangat sesuai). Alat ukur ini terdiri dari 44 butir pernyataan yang terbagi atas dua bagian komponen, antara lain motivational beliefs dan self-regulated learning strategies. Pada komponen motivational beliefs terdapat tiga buah dimensi, antara lain self-efficacy $(\alpha=0,81)$, instrinsic value $(\alpha=0,78)$, dan anxiety test $(\alpha=0,63)$. Sedangkan, pada komponen self-regulated learning strategies terdapat dua buah dimensi, antara lain cognitive strategy use $(\alpha=0,81)$ dan self-regulation $(\alpha=0,67)$.

MBI-SS dibuat dengan menggunakan tujuh skala $(0=$ tidak pernah sampai $6=$ selalu $)$. Alat ukur ini terdiri dari 15 butir pernyataan. Namun, hanya satu demensi yang digunakan yaitu dimensi emotional exhaustion $(\alpha=0,65)$. Alat ukur selanjutnya yang digunakan adalah UWES-S. UWES-S dibuat dengan menggunakan tujuh skala $(0=$ tidak pernah sampai $6=$ selalu $)$. Alat ukur ini terdiri dari 17 butir pernyataan yang terbagi atas tiga dimensi, yaitu vigor $(\alpha=0,79)$, dedication $(\alpha=0,73)$, dan absorption $(\alpha=0,67)$.

\section{HASIL DAN PEMBAHASAN}

Gambaran data untuk variabel self-regulated learning memiliki skor mean empirik sebesar 4,700. Skor mean empirik menunjukkan lebih tinggi dari mean hipotetik. Hal tersebut menunjukkan bahwa dimensi self-regulated learning yang dimiliki oleh partisipan penelitian cenderung tinggi. Selanjutnya, Gambaran data untuk variabel emotional exhaustion memiliki skor mean empirik sebesar 2,659. Skor mean empirik menunjukkan lebih tinggi dari mean hipotetik. Hal tersebut menunjukkan bahwa dimensi emotional exhaustion yang dimiliki oleh partisipan penelitian cenderung rendah. Gambaran data untuk variabel berikutnya, yaitu student engagement memiliki skor mean empirik sebesar 4,055. Skor mean empirik menunjukkan lebih tinggi dari mean hipotetik. Hal tersebut menunjukkan bahwa dimensi student engagement yang dimiliki oleh partisipan penelitian cenderung tinggi. Selengkapnya, dapat dilihat pada tabel 1.

Tabel 1

Gambaran Data Variabel Self-Regulated Learning, Emotional Exhaustion, dan Student Engagement

\begin{tabular}{lccccc}
\hline \multicolumn{1}{c}{ Dimensi } & $\mathrm{N}$ & Minimum & Maximum & Mean & SD \\
\hline Self-regulated learning & 424 & 2,34 & 6,21 & 4,700 & 0,668 \\
Emotional exhaustion & 424 & 0,00 & 6,00 & 2,659 & 1,233 \\
Student engagement & 424 & 0,11 & 5,76 & 4,055 & 0,954 \\
\hline
\end{tabular}

Berdasarkan hasil uji One sample $K-S$, terlihat bahwa data pada variabel self-regulated learning terdistribusi secara normal. Hal ini ditunjukkan melalui hasil pengujian normalitas terhadap variabel self-regulated learning dengan nilai Kolmogorov-Smirnov $\mathrm{Z}=0,667$ dan $\mathrm{p}=0,765>$ 0,05 . Selanjutnya, pada variabel emotional exhaustion dan variabel student engagement yang menunjukkan bahwa data terdistribusi normal. Pada emotional exhaustion, menunjukkan nilai Kolmogorov-Smirnov $\mathrm{Z}=0,873$ dan $\mathrm{p}=0,431>0,05$. Sedangkan, pada student engagement, menunjukkan nilai Kolmogorov-Smirnov $\mathrm{Z}=1,269$ dan $\mathrm{p}=0,080>0,05$. Selengkapnya, dapat dilihat pada tabel 2 . 
Tabel 2

Uji Normalitas Variabel Self-Regulated Learning, Emotional Exhaustion, dan Student Engagement

\begin{tabular}{lcccc}
\hline \multicolumn{1}{c}{ Dimensi } & $\mathrm{N}$ & $\mathrm{Z}$ & $\mathrm{p}$ & $\mathrm{SD}$ \\
\hline Self-regulated learning & 424 & 0,667 & 0,765 & 0,668 \\
Emotional exhaustion & 424 & 0,873 & 0,431 & 1,232 \\
Student engagement & 424 & 1,269 & 0,080 & 0,954 \\
\hline
\end{tabular}

Sebelum dilakukan uji regresi terhadap variabel self-regulated learning, emotional exhaustion, dan student engagement, terlebih dahulu dilakukan uji korelasi. Uji korelasi dilakukan sebanyak tiga pengujian, antara lain hubungan antara self-regulated learning dengan student engagement, self-regulated learning dengan emotional exhaustion, dan student engagement dengan emotional exhaustion. Berdasarkan analisis yang dilakukan dengan menggunakan korelasi Pearson diperoleh hasil $\mathrm{r}=0,531$ dan $\mathrm{p}=0,000<0,05$. Hal ini menunjukkan bahwa adanya hubungan positif signifikan pada variabel self-regulated learning dengan variabel student engagement. Semakin tinggi self-regulated learning, maka semakin tinggi student engagement. Sebaliknya, semakin rendah self-regulated learning, maka semakin rendah pula student engagement. Hasil ini mendukung penelitian sebelumnya yang dilakukan oleh Pizzimenti dan Axelson (2015) pada mahasiswa di Amerika Serikat, bahwa terdapat hubungan positif signifikan antara self-regulated learning terhadap student engagement. Dalam artian, semakin tinggi self-regulated learning yang dimiliki siswa, maka semakin tinggi pula student engagement yang dimilikinya. Sebaliknya, semakin rendah self-regulated learning yang dimiliki siswa, maka semakin rendah pula student engagement yang dimilikinya.

Selanjutnya, berdasarkan analisis yang dilakukan dengan menggunakan korelasi Pearson diperoleh hasil $\mathrm{r}=0,-312$ dan $\mathrm{p}=0,000<0,05$. Hal ini menunjukkan bahwa adanya hubungan negatif signifikan pada variabel self-regulated learning dengan variabel emotional exhaustion. Semakin tinggi self-regulated learning, maka semakin rendah emotional exhaustion. Sebaliknya, semakin rendah self-regulated learning, maka semakin tinggi emotinal exhaustion. Hasil ini mendukung penelitian sebelumnya yang dilakukan oleh Rigg et al. (2013) pada mahasiswa di Amerika Serikat. Dalam penelitiannya tidak dilakukan pengujian antara self-regulated learning dengan emotional exhaustion, melainkan hubungan antara self-efficacy dengan emotional exhaustion. Self-efficacy merupakan salah satu dimensi yang terdapat dalam self-regulated learning. Dalam artian, semakin tinggi self-regulated learning yang dimiliki siswa, maka semakin rendah emotional exhaustion yang dimilikinya. Sebaliknya, semakin rendah selfregulated learning yang dimiliki siswa, maka semakin tinggi emotional exhaustion yang dimilikinya.

Uji korelasi terakhir dilakukan pada variabel student engagemet terhadap emotional exhaustion. Berdasarkan analisis yang dilakukan dengan menggunakan korelasi Pearson diperoleh hasil $\mathrm{r}=$ $0,-121$ dan $\mathrm{p}=0,000<0,05$. Hal ini menunjukkan bahwa adanya hubungan negatif signifikan pada variabel student engagement dengan variabel emotional exhaustion. Semakin tinggi student engagement, maka semakin rendah emotional exhaustion. Sebaliknya, semakin rendah student engagement, maka semakin tinggi emotinal exhaustion. Hasil ini mendukung penelitian sebelumnya yang dilakukan oleh Rigg et al. (2013) pada mahasiswa di Amerika Serikat, bahwa terdapat hubungan antara student engagement dengan emotional exhaustion. Dalam artian, semakin tinggi student engagement yang dimiliki siswa, maka semakin rendah emotional 
exhaustion yang dimilikinya. Sebaliknya, semakin rendah student engagement yang dimiliki siswa, maka semakin tinggi emotional exhaustion yang dimilikinya.

Setelah diperoleh hasil uji korelasi, peneliti melanjutkan ke uji regresi linear langsung terhadap masing-masing variabel. Uji regresi dilakukan sebanyak tiga pengujian, antara lain hubungan antara self-regulated learning terhadap student engagement, self-regulated learning terhadap emotional exhaustion, dan student engagement terhadap emotional exhaustion. Berdasarkan analisis yang dilakukan dengan menggunakan regresi linear, diperoleh hasil $\mathrm{R}^{2}=0,282 ; \beta_{\mathrm{a}}=$ 0,$531 ; \mathrm{t}=12,870$; dan $\mathrm{p}=0,000<0,05$. Hal ini menunjukkan bahwa ada pengaruh positif signifikan dari self-regulated learning terhadap student engagement dengan besar pengaruh $28,2 \%$, sedangkan sisanya $71,8 \%$ dipengaruhi oleh faktor lain. Berdasarkan analisis yang dilakukan dengan menggunakan regresi linear, diperoleh hasil $\mathrm{R}^{2}=0,097 ; \beta_{\mathrm{c}}=-0,312 ; \mathrm{t}=-6,752$; dan $\mathrm{p}=0,000<0,05$. Hal ini menunjukkan bahwa ada pengaruh negatif signifikan dari selfregulated learning terhadap emotional exhaustion dengan besar pengaruh 9,7\%, sedangkan sisanya 90,3\% dipengaruhi oleh faktor lain. Berdasarkan analisis yang dilakukan dengan menggunakan regresi linear, diperoleh hasil $\mathrm{R}^{2}=0,015 ; \beta_{\mathrm{b}}=-0,121 ; \mathrm{t}=-2,496$; dan $\mathrm{p}=0,013>$ 0,05. Hal ini menunjukkan bahwa ada pengaruh negatif signifikan dari student engagement terhadap emotional exhaustion dengan besar pengaruh 1,5\%, sedangkan sisanya 98,5\% dipengaruhi oleh faktor lain.

Setelah uji korelasi dan uji regresi linear langsung telah terpenuhi, uji regresi dengan menggunakan mediasi dapat dilakukan. Berdasarkan analisis yang dilakukan dengan menggunakan regresi linear, diperoleh hasil $\beta_{\mathrm{b}^{\prime}}=0,063$ dan $\beta_{\mathrm{c}^{\prime}}=-0,346$ dengan nilai $\mathrm{t} b^{\prime}=1,153$; $\mathrm{p}=0,250>0,05$ dan $\mathrm{t} c^{\prime}=-6,336 ; \mathrm{p}=0,000<0,05$. Hal tersebut menunjukkan bahwa selfregulated learning secara negatif signifikan memengaruhi emotional exhaustion dan student engagement tidak memediasi peran self-regulated learning terhadap emotional exhaustion. Hal ini dapat terlihat dari nilai $\mathrm{t} b^{\prime}=1,153<1,900$ dan nilai $\mathrm{t} b^{\prime}<\mathrm{t} c^{\prime}$. Dengan demikian, kriteria student engagement sebagai mediator tidak terpenuhi. Selengkapnya dapat dilihat pada tabel 3.

Tabel 3

Uji Regresi Variabel Self-Regulated Learning terhadap Variabel Emotional Exhaustion dengan Variabel Student Engagement sebagai Mediator

\begin{tabular}{ccccc}
\hline IV & Koefisien & B & t & p \\
\hline Self-regulated learning & c' & $-0,346$ & $-6,336$ & 0,000 \\
Student engagement & b' & 0,063 & 1,153 & 0,250 \\
\hline
\end{tabular}

Berdasarkan hasil temuan yang diperoleh peneliti, menunjukan bahwa hasil tersebut menolak hasil penelitian sebelumnya yang ditemukan oleh Rig et al. (2013) yang menjelaskan bahwa student engagement memediasi peranan self-efficacy terhadap emotional exhaustion.

Hasil analisis yang diperoleh peneliti saat melakukan uji regresi linear langsung terhadap masing-masing variabel adalah terdapat pengaruh positif signifikan antara self-regulated learning terhadap student engagement, terdapat pengaruh negatif signifikan antara self-regulated learning terhadap emotional exhaustion, dan terdapat pengaruh negatif signifikan antara student engagement terhadap emotional exhaustion. Dengan kata lain, ketika siswa memiliki selfregulated learning yang tinggi, maka akan menyebabkan tingginya student engagement yang dimiliki siswa tersebut. Sebaliknya, ketika siswa memiliki self-regulated learning yang rendah, maka akan menyebabkan rendahnya student engagement yang dimiliki siswa tersebut. 
Selanjutnya, ketika siswa memiliki self-regulated learning yang tinggi, maka akan menyebabkan rendahnya emotional exhaustion yang dimiliki siswa tersebut. Sebaliknya, ketika siswa memiliki self-regulated learning yang rendah, maka akan menyebabkan tingginya emotional exhaustion yang dimiliki siswa tersebut. Serupa dengan pengaruh self-regulated learning terhadap emotional exhaustion, ketika siswa memiliki student engagement yang tinggi, maka akan menyebabkan rendahnya emotional exhaustion yang dimiliki siswa tersebut. Sebaliknya, ketika siswa memiliki student engagement yang rendah, maka akan menyebabkan tingginya emotional exhaustion yang dimiliki siswa tersebut.

Namun, ketika uji regresi dilakukan dengan mediasi, yang terjadi adalah berubahnya pengaruh mediator terhadap dependent variabel menjadi tidak signifikan. Menurut Baron dan Kenny (1986), salah satu faktor penyebab gagalnya suatu variabel dalam memediasi adalah karena adanya faktor lain yang dapat memengaruhi kemunculan dependent variabel. Oleh sebab itu, langkah yang digunakan peneliti untuk mengkaji penyebab gagalnya mediasi ini adalah dengan meninjau kembali faktor yang dapat mempengaruhi kemunculan dependent variabel, dalam hal ini adalah emotional exhaustion.

Emotional exhaustion dapat terjadi pada siswa dikarenakan pengalaman stres yang berlebihan akibat dari adanya tuntutan tugas yang terus-menerus, kepribadian yang dimiliki siswa, adanya batas waktu dalam menyelesaikan tugas, dan tingginya tuntutan dari lingkungan dapat memperburuk stres pada siswa (Schaufeli, Martinez, Marques Pinto, Salanova, \& Bakker dikutip dalam Rigg et al., 2013). Namun, yang menjadi kekhasan pada santri adalah tingginya selfregulated learning yang dimiliki oleh santri. Hal ini dapat dilihat berdasarkan gambaran variabel self-regulated learning yang diperoleh peneliti. Skor mean empirik dalam variabel self-regulated learning pada santri berada di atas nilai mean hipotetik yang berarti bahwa self-regulated learning pada santri cenderung tinggi. Hal ini juga didukung oleh temuan penelitian yang dilakukan oleh Shukor, Jasmi, dan Noor (2013) yang menjelaskan bahwa santri yang menempuh pendidikan di dalam pondok pesantren memiliki strategi pengaturan belajar atau self-regulated learning yang tinggi yang berdampak pada performa atau kinerja belajar yang baik.

Selain itu, skor pengaruh independent variabel terhadap dependent variabel terbesar diperoleh pada pengaruh self-regulated learning terhadap emotional exhaustion atau $\mathrm{t} c$ ' $>\mathrm{t} b$ '. Sehingga, berdasarkan hasil penelitian yang diperoleh, dapat terlihat bahwa pengaruh self-regulated learning terhadap emotional exhaustion lebih tinggi dibandingkan dengan pengaruh stundent engagement terhadap emotional exhaustion. Dengan kata lain, pengaruh self-regulated learning terhadap emotional exhaustion dapat terjadi secara langsung tanpa harus melalui mediasi.

Hal lain yang juga dinilai sebagai salah satu faktor penyebab gagalnya variabel mediator adalah alat ukur yang digunakan untuk mengukur variabel mediator atau student engagement (UWESS) lebih banyak digunakan pada partisipan penelitian dengan rentang usia di atas 19 tahun. Sedangkan, dalam penelitian ini, partisipan penelitian berada pada rentang usia 11-20 tahun dengan jumlah usia terbesar berada pada rentang usia 11-14 tahun. Sehingga, meskipun alat ukur tersebut telah diperuntukkan penggunaannya terhadap siswa, namun tingkat kematangan siswa yang menjadi partisipan dalam penelitian yang peneliti lakukan tidak sama dengan tingkat kematangan penelitian sebelumnya (Schaufeli \& Bakker, 2003) yang berdampak pada berbedanya pemahaman terhadap setiap butir pernyataan yang terdapat dalam alat ukur tersebut. 


\section{KESIMPULAN DAN SARAN}

Penelitian ini bertujuan untuk mengetahui peranan self-regulated learning terhadap emotional exhaustion yang dimediasi oleh student engagement pada santri. Analisis data utama dilakukan dengan menggunakan analisis regresi linear. Berdasarkan hasil analisis yang diperoleh, tiga hipotesis dalam penelitian ini diterima dan satu hipotesis penelitian ditolak. Adapun hipotesis yang diterima antara lain, pertama terdapat pengaruh self-regulated learning terhadap emotional exhaustion dengan $\mathrm{R}^{2}=0,097$ dan $\mathrm{p}=0,000<0,05$. Artinya, self-regulated learning memiliki kontribusi sebesar 9,7\%, sedangkan sisanya 90,3\% dipengaruhi oleh faktor lain. Berikutnya, hipotesis kedua yaitu terdapat pengaruh self-regulated learning terhadap student engagement dengan $\mathrm{R}^{2}=0,282$ dan $\mathrm{p}=0,000<0,05$. Dengan kata lain, self-regulated learning memiliki kontribusi sebesar $28,2 \%$, sedangkan sisanya $71,8 \%$ dipengaruhi oleh faktor lain. Hipotesis ketiga yaitu terdapat pengaruh student engagement terhadap emotional exhaustion dengan $\mathrm{R}^{2}=$ 0,015 dan $\mathrm{p}=0,013>0,05$. Dengan kata lain, student engagement memiliki kontribusi sebesar $1,5 \%$, sedangkan sisanya $98,5 \%$ dipengaruhi oleh faktor lain. Sedangkan, hipotesis yang ditolak adalah tidak terpenuhinya kriteria student engagement dalam memediasi peranan self-regulated learning terhadap emotional exhaustion dengan nilai $\mathrm{t} b^{\prime}=1,153<1,900$ dan $\mathrm{p}=0,250>0,05$. Sehingga, untuk mengetahui peranan self-regulated learning terhadap emotional exhaustion dapat dilakukan dengan cara regresi linear langsung tanpa melalui proses mediasi. Hal ini dapat terlihat dari perolehan nilai $t c^{\prime}=-6,336$ lebih besar dari $t b^{\prime}=1,153$, yang menunjukkan bahwa pengaruh self-regulated learning terhadap emotional exhaustion lebih besar dibandingkan dengan pengaruh student engagement terhadap emotional exhaustion.

Berdasarkan hasil temuan yang peneliti peroleh, peneliti menemukan bahwa nilai pengaruh independent variabel terhadap dependent variable lebih besar dibandingkan dengan nilai pengaruh variabel mediator terhadap dependent variable. Sehingga, dengan adanya temuan tersebut peneliti berharap agar pada penelitian selanjutnya dapat dilakukan pengubahan fungsi variabel yaitu diubahnya independent variable menjadi variabel mediator. Begitupun sebaliknya, diubahnya variabel mediator menjadi independent variable. Hal ini dilakukan untuk melihat peran self-regulated learning sebagai mediator pada student engagement terhadap emotional exhaustion.

Selanjutnya, peneliti juga berharap agar pada penelitian selanjutnya dapat melakukan variasi terhadap metode penelitian yang digunakan dengan tujuan untuk memperkaya hasil penelitian yang diperoleh, misalnya dengan menggunakan metode kualitatif ataupun dengan mix method atau triangulasi, yaitu menggabungkan dua atau lebih metode penelitian dalam satu kegiatan penelitian. Peneliti juga menyarankan agar pada penelitian berikutnya dapat dilakukan replikasi penelitian pada partisipan yang berbeda, seperti guru atau staf pengajar. Karena, salah satu hal yang membangun semangat siswa dalam bersekolah adalah hubungan dengan guru. Namun, banyak kemungkinan yang akan muncul ketika guru memiliki emotional exhaustion. Sehingga, untuk mengetahui faktor dan dampak yang mungkin muncul dari guru tersebut perlu dilakukan penelitian lebih lanjut. Dengan begitu, suasana pembelajaran yang lebih nyaman dapat lebih tercipta.

\section{REFERENSI}

Abdullah, M. C., Teoh, H. C., Roslan, S., \& Uli, J. (2015). Student engagement: Concepts, development and application in Malaysian universities. Journal of Educational and Social
Research, $5(2)$,
275-284.
Retrieved
from: 
file:///C:/Users/WINDOWS\%2010/Downloads/StudentEngagementConceptsDevelopmenta ndApplicationinMalaysianUniversities.pdf

Baron, R.M., \& Kenny, D.A. (1986). The moderator-mediator variable distiction in social psychological research: Conceptual, strategic, and statistical considerations. Journal of Personality and Social Psychology, 56(6), 1173-1182. Retrieved from http://citeseerx.ist.psu.edu/viewdoc/download?doi=10.1.1.169.4836\&rep=rep1\&type=pdf

Capri, B., Gunduz, B., \& Akbay, S. E. (2017). Utrecht work engagement scale-student forms' (uwes-sf) adaptation to Turkish, validity and reliability studies, and the mediator role of work engagement between academic procrastination and academic responsibility. Educational Sciences Theory and Practice, 17(2), 411-435.

Hidayat, M. (2016). Model komunikasi kyai dengan santri di pesantren. Jurnal Komunikasi ASPIKOM, 6(2), 385-395. Diunduh dari: file:///C:/Users/WINDOWS\%2010/Downloads/89155-1-SM.pdf

$\mathrm{Hu}$, Q., \& Schaufeli, W. B. (2009). The factorial validity of the maslach burnout inventorystudent survey in china. Psychological Reports, 105, 394-408.

Maslach, C., Schaufeli, W. B., Leiter, M. P. (2001). Job burnout. Annu Rev. Psychol., 52, $397-$ 422.

Pizzimenti, M. A, \& Axelson, R. D. (2015). Assessing student engagement and self-regulated learning in a medical gross anatomy course. Anatomical Sciences Education, 8, 104-110.

Rahmati, Z. (2015). The study of academic burnout in students with high and low level of selfefficacy. Procedia: Social and Behavioral Sciences, 171, 49-55.

Rigg, J., Day, J., \& Adler, H. (2013). Emotional exhaustion in graduate students: The role of engagement, self-efficacy and social support. Journal of Educational and Developmental Psychology, 2(3), 138-150.

Rőmer, J. (2016). The korean utrecht work engagement scale-student (UWES-S): A factor validation study. TPM, 1(23), 65-81.

Saridjo, M. (1983). Sejarah pondok pesantren di Indonesia. Jakarta: Dharma Bakti.

Santrock, J. W. (2012). Educational psychology (5th ed.). New York: McGraw Hill.

Schunk, D. H., \& Zimmerman, B. J. (2012). Motivation and self-regulated learning: Theory, research, and applications. New York: Routledge.

Snowman, J., McCown, R., \& Biehler, R. (2009). Psychology applied to teaching (12th Ed.). New York: Houghton Mifflin.

Taylor, L., \& Parsons, J. (2011). Improving student engagement. Current Issues in Education, 14(1), 1-33. Retrieved from: file:///C:/Users/WINDOWS\%2010/Downloads/745Article\%20Text-2766-1-10-20110506.pdf

Tuithof, M., Have, M. T., Beekman, A., Dorsselaer, S. V., Kleinjan, M., Schaufeli, W., \& Graaf, R. D. (2017). The interplay between emotional exhaustion, common mental disorders, functioning and health care use in the working population. Journal of Psychosomatic Research, 8-14.

Wickramasinghe, N. D., Dissanayake, D. S., \& Abeywardena, G. S. (2018). Validity and reliability of the utrecht work engagement scale-student version in Sri Lanka. BMC Research Notes, 11(277), 1-6.

Wolters, C. A., \& Taylor, D. J. (2012). A self-regulated learning perspective on student engagement. Handbook of Research on Student Engagement. 